\title{
THE EFFECT OF DIFFERENT FIXED FACTORS ON PIG CARCASS QUALITY AND MEAT TRAITS
}

\section{Č. Radović1 ${ }^{1}$ M. Petrović ${ }^{2}$, O. Kosovac ${ }^{1}$, N. Stanišićc ${ }^{1}$, D. Radojković ${ }^{2}$, M. Mijatović ${ }^{2}$}

${ }^{1}$ Institute for Animal Husbandry, Belgrade - Zemun, ${ }^{2}$ Faculty of Agriculture, Zemun, 11080

Corresponding author:

Čedomir Radović, e-mail: cedomirradovic.izs@gmail.com

Original scientific paper

Research was financed by the Ministry of Science of Republic of Serbia within project TR 20087

\begin{abstract}
Objective of the paper was to investigate the effect of the sire breed (Swedish landrace and Large Yorkshire) and sex (female animals and male castrates) on quality of carcass and pig meat. Established fat thickenss was the highest at withers $(33,21 \mathrm{~mm})$ and the thinnest at rump in the center of m. gluteusa medius $(18,48 \mathrm{~mm})$. Sire breed had influence $(\mathrm{p}<0,01)$ on back fat thickness in the central part, whereas sex influenced $(p<0,05)$ backfat thickenss at withers. Lean meat of Swedish Landrace progeny established by partial dissection EU was 52,91 $\%$ and according to current Regulation $42,89 \%$ and it was higher compared to progeny (SLXLY) whose sires were Large Yorkshire breed. Established difference in share of meat between sire breeds by application of these two methods was 10,02 and $8,83 \%$. Higher share of meat (EU 53,20\%) was established in female progeny by $2,27 \%$ in comparison to male progeny $(p<0,05)$. Also, sire breed influenced $(\mathrm{p}<0,05$ and $\mathrm{p}<0,01) \mathrm{pH}$, water binding capacity, softness and thickenss of muscle fibre, whereas the sex influenced $(\mathrm{p}<0,01)$ colour of musculus longissimus. Sire breed and sex had no influence on investigated chemical traits of m. longissimus $(\mathrm{p}>0,05)$.
\end{abstract}

Key words: sire, breed, genotype, sex, carcass quality, meat quality

\section{Introduction}

Production of pigs and pork meat depend on numerous factors. Major factors influencing the quantity and quality of carcass are genetic and environment factors (sires, breeding method, age and mass at slaughtering, castration, nutrition, handling before, during and after slaughtering, etc.). It is known that certain quantitative pig traits are inherited unevenly, which means that possibilities for their improvement through selection are different. Heritability coefficients for fattening traits and traits of carcass side quality were medium to high (Knapp et 
al., 1997, Radović et al. 2003). Numerous researches have been published on the effect of genotype on quality of carcass and pig meat (Fisher et al. 2003, Kosovac et al. 2002, Radović et al. 2003, Petrović et al., 2004, Jukna and Jukna 2005, Radović et al. 2008) where the effect of breed i.e. genotype on carcass quality and pig meat was established. In Serbia, Regulation (Official journal SFRY, 2/851985) is still used for establishing of total mass of muscle tissue without meat from bellyrib part. Meat content determined according to Regulation was lower than meat content determined using FOM or dissection according to methodology recommended by EU.

Objective of this paper was to establish the effect of sire breed and sex on quality of carcass sides and meat, as well as how much the share of meat determined using the current Regulation is lower compared to recommended EU methodology.

\section{Material and methods}

Research was carried out in salughterhouse of the Institute for Animal Husbandry in Zemun. In slaughterhouse, for every fattening pig - progeny the following was regcorded: tatoo number, sex, date of slaughtering, mass of warm carcass side, five measurments of back fat (withers, central back and rump at the beginning, center and at the end of $m$. gluteusa mediusa), length of carcass side Os pubis-atlas and Os pubis-first rib. Share of meat in carcass sides was determined using tables for meat pigs according to Regulation on the quality of slaughtered pigs and categorization of pig meat (OJ SFRY, 1985) and according to procedure recommended by EU where subsequent to cooling the quality of carcass sides was determined, i.e. lean meat in carcass sides using the method of partial dissection (Commission Regulation (EC) No 3127/94... 1994) described in detail by Walstra and Merkus (1996).

Investigation included 29 progeny deriving from mothers of Swedish Landrace breed and sires of Swedish Landrace breed ( $\mathrm{n}=14$ progeny animals) and large Yorkshire breed ( $\mathrm{n}=15$ progeny animals). Of total number of progeny, 15 heads were male castrates and 14 were females.

Samples for chemical, technological and biological meat quality were taken from the second back muscle musculus longissimus (ML), between 13th and 14th rib.

Water content was determined by reference method according to JUS ISO 1442 (1998), free lipids by method JUS ISO 1444 (1998), content of ashes was determined by method of burning according to JUS ISO 936 (1999). Water binding ability was determined according to method by Grau and Hamm (1953) expressed in $\%$ of bound water, colour of meat was determined according to Hart and softness according to Wolodkewisch. Surface of ML was measured by method of 
planimetry and diamter of muscle fibre subsequent to conservation by method of maceration was measured using microscope.

Preparation of data base for statistical processing was done applying dBase $I I I^{+}$program. Phenbotype variability of traits was calcualted by application of different models of the method of Least Squares (LSMLMW and MIXMDL-Harvey, 1990). Sire breed, sex and mass of warm carcass sides for traits on salughter line (regression effect) were included in models.

\section{Results and discussion}

Average values and variability of traits measured on slaughter line are presented in table 1. Table shows that the thinnest back fat was measured at rump II, and the thickest at withers. Average value of share of meat established according to current Regulation is lower by $9,4 \%$ than value obtained using recommended procedure by EU with same average mass of warm carcass side of $76,66 \mathrm{~kg}$.

Table 1. Average values and variability of carcass quality traits of progeny $\left(\mathrm{MWCS}=76,66 \mathrm{~kg}^{1}\right)$

\begin{tabular}{|c|c|c|c|c|}
\hline \multicolumn{3}{|c|}{ Trait } & $\bar{x} \pm S d$ & $\mu \pm$ S.E. \\
\hline WFT & \multicolumn{2}{|l|}{ Withers fat thickness, mm } & $33,21 \pm 6,56$ & $33,18 \pm 1,13$ \\
\hline BFTC & \multicolumn{2}{|c|}{ Back fat thickness in the center, $\mathrm{mm}$} & $19,34 \pm 3,92$ & $19,29 \pm 0,67$ \\
\hline \multirow{3}{*}{ RFT } & \multirow{3}{*}{ Rump fat thickness, mm } & I & $25,34 \pm 4,47$ & $25,33 \pm 0,86$ \\
\hline & & II & $18,48 \pm 4,46$ & $18,43 \pm 0,84$ \\
\hline & & III & $24,41 \pm 4,93$ & $24,31 \pm 0,88$ \\
\hline CSLOPA & \multicolumn{2}{|c|}{ Cacrass side length Os pubis-atlas, $\mathrm{cm}$} & $96,88 \pm 3,24$ & $96,87 \pm 0,54$ \\
\hline CSLOFR & \multicolumn{2}{|c|}{ Carcass side length Os pubis-first rib, $\mathrm{cm}$} & $79,71 \pm 2,45$ & $79,69 \pm 0,39$ \\
\hline M-JUS & \multicolumn{2}{|c|}{ Share of meat in carcass sides, $\%$} & $42,59 \pm 1,26$ & $42,60 \pm 0,24$ \\
\hline M-EU & \multicolumn{2}{|c|}{$\begin{array}{l}\text { Share of meat in carcass sides, EU } \\
\text { method, } \%\end{array}$} & $51,99 \pm 3,19$ & $52,06 \pm 1,26$ \\
\hline
\end{tabular}

Traits adjusted to same average mass of warm carcass sides $(\mathrm{MWCS}=76,66 \mathrm{~kg})$

In table 2. the effect of sire breed and sex of progeny on back fat thickness is presented. Sire breed had influence $(\mathrm{p}<0,01)$ on back fat thickness in the center, whereas the sex had effect $(\mathrm{p}<0,05)$ on back fat thickness at withers. Investigated factors had no influence on other values of back fat thickness $(p>0,05)$. 
Table 2. The effect of sire breed, sex on back fat thickness in progeny (LSM \pm S.E.)

\begin{tabular}{|c|c|c|c|c|c|}
\hline \multirow{2}{*}{$\begin{array}{c}\text { Variation } \\
\text { sources }\end{array}$} & \multirow{2}{*}{ WFT, mm } & \multirow{2}{*}{ BFTC, mm } & \multicolumn{3}{|c|}{ RFT, mm } \\
\cline { 4 - 6 } & & & I & II & III \\
\hline $\begin{array}{c}\text { Sire breed } \\
\text { 1.SL }\end{array}$ & $34,98 \pm 1,76$ & $17,56 \pm 0,87$ & $25,51 \pm 1,30$ & $17,83 \pm 1,18$ & $23,16 \pm 1,40$ \\
$2 . \mathrm{LY}$ & $31,70 \pm 1,70$ & $21,13 \pm 0,84$ & $25,25 \pm 1,26$ & $19,09 \pm 1,14$ & $25,58 \pm 1,35$ \\
\hline $\mathrm{P}$ & $\mathrm{NS}$ & $* *$ & $\mathrm{NS}$ & $\mathrm{NS}$ & $\mathrm{NS}$ \\
\hline Sex & & & & & \\
M & $35,52 \pm 1,57$ & $19,00 \pm 0,94$ & $25,95 \pm 1,20$ & $19,15 \pm 1,17$ & $25,81 \pm 1,23$ \\
$\mathrm{~F}$ & $30,87 \pm 1,64$ & $19,58 \pm 0,98$ & $24,71 \pm 1,25$ & $17,70 \pm 1,22$ & $22,82 \pm 1,28$ \\
\hline $\mathrm{P}$ & $*$ & $\mathrm{NS}$ & $\mathrm{NS}$ & $\mathrm{NS}$ & $\mathrm{NS}$ \\
\hline MWCS (b) & $0,220^{\mathrm{NS}}$ & $0,207^{\mathrm{NS}}$ & $0,114^{\mathrm{NS}}$ & $0,209^{\mathrm{NS}}$ & $0,279^{\mathrm{NS}}$ \\
\hline
\end{tabular}

1) ŠL- Swedish Landrace, LY- Large Yorkshire, P -NS $=\mathrm{P}>0,05 ;{ }^{*}=\mathrm{P}<0,05 ;{ }^{* *}=\mathrm{P}<0,01,{ }^{2} \mathrm{M}-$ male castrated animals, F - females, MWCS (b)- linear effect of the mass of warm carcass side, WFT- back fat thickness at withers, BFTC - back fat thickness in the center, RFT- back fat thickness at rump I, II, III

Sire breed had no effect on length of carcass side and lean meat of progeny (table 3), whereas the sex of progeny influenced $(p<0,05)$ the lean meat determined according to EU recommended methodology. Linear effect of the mass of warm carcass side on carcass side length was statistically highly significant $(p<0,01)$.

Table 3. The effect of sire breed and sex on carcass side length and lean meat of progeny (LSM \pm S.E.)

\begin{tabular}{|c|c|c|c|c|}
\hline $\begin{array}{c}\text { Sources of } \\
\text { variation }\end{array}$ & CSLOPA, cm & CSLOFR, cm & M-JUS, $\%$ & M-EU, \% \\
\hline $\begin{array}{c}\text { Sire breed } \\
\text { 1.SL }\end{array}$ & $96,19 \pm 0,81$ & $79,65 \pm 0,58$ & $42,89 \pm 0,32$ & $52,91 \pm 0,84$ \\
$2 . \mathrm{LY}$ & $97,50 \pm 0,78$ & $79,71 \pm 0,56$ & $42,27 \pm 0,31$ & $51,10 \pm 0,81$ \\
\hline P & $\mathrm{NS}$ & $\mathrm{NS}$ & $\mathrm{NS}$ & $\mathrm{NS}$ \\
\hline Sex & & & & \\
M & $96,59 \pm 0,75$ & $80,10 \pm 0,55$ & $42,53 \pm 0,33$ & $50,93 \pm 0,72$ \\
F & $97,14 \pm 0,78$ & $79,28 \pm 0,57$ & $42,67 \pm 0,35$ & $53,20 \pm 0,75$ \\
\hline P & $\mathrm{NS}$ & $\mathrm{NS}$ & $\mathrm{NS}$ & $*$ \\
\hline MWCS (b) & $0,369^{* *}$ & $0,306^{* *}$ & $0,011^{\mathrm{NS}}$ & $0,151^{\mathrm{NS}}$ \\
\hline
\end{tabular}

${ }^{1)}$ SL- Swedish Landrace, LY- Large Yorkshire, P -NS $=\mathrm{P}>0,05 ;{ }^{*}=\mathrm{P}<0,05 ; * *=\mathrm{P}<0,01,{ }^{2} \mathrm{M}-$ male castrated animals, F - females, MWCS (b)- linear effect of the mass of warm carcass side, CSLOPA - carcass side length Os pubis-atlas, CSLOFR - carcass side length Os pubis-first rib, M-JUS share of meat in carcass sides, M-EU share of meat determined by method of partial dissection

In the research by Radović et al. (2003), even with lower mass of warm carcass sides $(74,17 \mathrm{~kg})$ higher values were established for back fat thickness as well as lower share of meat in carcass sides using the Regulation (1985) and in repeated research (Radović et al. 2008) where average mass of warm carcass side was higher $81,47 \mathrm{~kg}$, lower values for back fat thickness and higher share of meat 
were established compared to our results. Radović et al.(2003) and Radović et al. (2008) established the effect of sire breed $(\mathrm{p}<0,01)$ on back fat thickenss and share of meat which is contrary to our research, except for back fat thickenss in the center. Established values for carcass side length are similar to values obtained by Pušić (1996). The effect of sex $(\mathrm{p}<0,05)$ on share of meat was established by EU recommended methodology. Progeny of Swedish landrace genotype in this paper had higher share of meat according to EU methodology $(1,61 \%)$ compared to research by Kosovac et al. (2008).

In table 4., average values and variability of investigated chemical, technological and biological traits of m. longissimus (ML) are presented.

Table 4. Average values and variability of investigated ML traits

\begin{tabular}{|l|c|c|}
\hline \multicolumn{1}{|c|}{ Trait } & $\bar{x} \pm S d$ & $\mu \pm$ S.E. \\
\hline Area of ML, $\mathrm{cm}^{2}$ & $43,62 \pm 8,98$ & $43,72 \pm 1,55$ \\
\hline pH of ML & $5,54 \pm 0,16$ & $5,53 \pm 0,16$ \\
\hline Water, \% & $73,00 \pm 0,77$ & $73,03 \pm 1,35$ \\
\hline Lipids, \% & $1,71 \pm 0,57$ & $1,70 \pm 0,10$ \\
\hline Ashes, \% & $1,17 \pm 0,46$ & $1,17 \pm 0,01$ \\
\hline Protein, \% & $24,11 \pm 0,86$ & $24,09 \pm 0,15$ \\
\hline Water binding capacity, \% & $57,55 \pm 1,17$ & $57,00 \pm 0,19$ \\
\hline Colour & $0,359 \pm 0,08$ & $0,351 \pm 0,01$ \\
\hline Softness, kg & $5,30 \pm 1,94$ & $5,42 \pm 0,33$ \\
\hline Muscle tissue thickness, $\mu \mathrm{m}$ & $63,78 \pm 6,34$ & $64,32 \pm 1,04$ \\
\hline Cooking loss, \% & $31,78 \pm 1,92$ & $31,88 \pm 0,33$ \\
\hline Roasting loss, \% & $34,32 \pm 1,57$ & $34,38 \pm 0,27$ \\
\hline
\end{tabular}

Sire breed and sex exhibited no significant effect $(p>0,05)$ on investigated chemical traits of ML (Table 5.), whereas in the research by Jukna and Jukna (2005) differences $(p<0,05)$ for protein and fat $(p<0,05$ andp $<0,001)$ between certain genotypes were established.

Table 5. The effect of sire breed and sex of progeny on chemical composition of ML (LSM \pm S.E.)

\begin{tabular}{|c|c|c|c|c|}
\hline $\begin{array}{c}\text { Sources of } \\
\text { variation }\end{array}$ & Water, \% & Lipids, \% & Ashes, $\%$ & Protein, $\%$ \\
\hline $\begin{array}{c}\text { Sire breed } \\
1 . \mathrm{SL}^{1)}\end{array}$ & $73,14 \pm 0,21$ & $1,63 \pm 0,16$ & $1,17 \pm 0,01$ & $24,05 \pm 0,24$ \\
$2 . \mathrm{LY}$ & $72,91 \pm 017$ & $1,76 \pm 0,13$ & $1,18 \pm 0,01$ & $24,14 \pm 0,20$ \\
\hline P & NS & NS & NS & NS \\
\hline Sex $^{2)}$ & & & & \\
M & $72,98 \pm 0,18$ & $1,69 \pm 0,13$ & $1,17 \pm 0,01$ & $24,15 \pm 0,20$ \\
F & $73,08 \pm 0,20$ & $1,70 \pm 0,15$ & $1,18 \pm 0,01$ & $24,03 \pm 0,22$ \\
\hline P & NS & NS & NS & NS \\
\hline
\end{tabular}

${ }^{1)}$ SL- Swedish Landrace, LY- Large Yorkshire, $\mathrm{P}-\mathrm{NS}=\mathrm{P}>0,05 ; *=\mathrm{P}<0,05 ; * *=\mathrm{P}<0,01,{ }^{2} \mathrm{M}$ - male castrated animals, $\breve{Z}$ - females 
In table 6 . we see that sire breed had effect $(\mathrm{p}<0,05$ and $\mathrm{p}<0,01)$ on $\mathrm{pH}$, WBC, softness and thickness of the muscle tissue, and sex of progeny animals on colour of ML. These two factors had no ingluence on other traits $(\mathrm{p}>0,05)$. For progeny of Swedich Landrace genotype higher water binding capacity was established and lower value for colour compared to research of Kosovac et al. (2008).

Table 6. The effect of sire breed and sex of progeny on technological and biological quality traits of ML (LSM \pm S.E.)

\begin{tabular}{|c|c|c|c|c|c|c|}
\hline \multirow{2}{*}{$\begin{array}{l}\text { Trait/ Source of } \\
\text { variation }\end{array}$} & \multicolumn{2}{|c|}{ Sire breed } & \multirow[b]{2}{*}{$\mathrm{P}$} & \multicolumn{2}{|c|}{ Sex } & \multirow[b]{2}{*}{$\mathrm{P}$} \\
\hline & $\begin{array}{l}\text { Swedish } \\
\text { Landrace }\end{array}$ & $\begin{array}{c}\text { Large } \\
\text { Yorkshire }\end{array}$ & & Male & Female & \\
\hline $\mathrm{pH}$ & $5,49 \pm 0,25$ & $5,57 \pm 0,20$ & $*$ & $5,54 \pm 0,21$ & $5,52 \pm 0,23$ & NS \\
\hline $\mathrm{WBC}^{1)}$ & $54,57 \pm 0,28$ & $59,52 \pm 0,23$ & $* *$ & $57,50 \pm 0,25$ & $56,55 \pm 0,27$ & $\mathrm{NS}$ \\
\hline Cooking loss, $\%$ & $32,36 \pm 0,52$ & $31,39 \pm 0,42$ & NS & $31,85 \pm 0,44$ & $31,91 \pm 0,48$ & $\mathrm{NS}$ \\
\hline Roasting loss, $\%$ & $34,72 \pm 0,44$ & $34,06 \pm 0,36$ & $\mathrm{NS}$ & $34,42 \pm 0,37$ & $34,35 \pm 0,40$ & NS \\
\hline Softness, kg & $5,99 \pm 0,46$ & $4,83 \pm 0,37$ & $*$ & $5,38 \pm 0,44$ & $5,46 \pm 0,48$ & $\mathrm{NS}$ \\
\hline Colour & $0,331 \pm 0,02$ & $0,378 \pm 0,02$ & NS & $0,383 \pm 0,01$ & $0,320 \pm 0,01$ & $* *$ \\
\hline $\begin{array}{l}\text { Thickness of muscle } \\
\text { tissue, } \mu \mathrm{m}\end{array}$ & $66,30 \pm 1,67$ & $62,10 \pm 1,36$ & $*$ & $63,04 \pm 1,39$ & $65,61 \pm 1,53$ & NS \\
\hline
\end{tabular}

$\mathrm{P}-\mathrm{NS}=\mathrm{P}>0,05 ; *=\mathrm{P}<0,05 ; * *=\mathrm{P}<0,01,{ }^{1)} \mathrm{WBC}$ - water binding capacity

Thickness of muscle fibre established in our research was in interval from 62,10 to $66,30 \mu \mathrm{m}$. Investigating two parts of ML ( $m$. longissimus thoracis and m. longissimus lumborum) Migdal et al. (2005) established that diameter of muscle fibre was from 52,14 to $100,67 \mu \mathrm{m}$.

\section{Conclusion}

Main goal of selection and other measures in pig breeding is increase of quantity of major meat sections in carcass sides but with preserved quality of pig meat, i.e. that adequate hygiene-toxicological, technological, chemical and sensory traits are maintained. Quality of pig carcasses and meat has effect on competitiveness of production and market demands.

Research was carried out in order to investigate the effect of sire breed and sex of progeny on quality of carcass and pig meat. Based on the research it can be concluded that investigated factors can have significant effect $(p<0,05$ and $p<0,01)$ on certain traits of carcass quality, as well as on technological and biological traits of $m$. longissimus. For investigated chemical traits of $m$. longissimus no effect of investigated factors was established $(\mathrm{p}>0,05)$. 


\title{
Uticaj različitih fiksnih faktora na osobine kvaliteta trupa i mesa svinja
}

\author{
Č. Radović, M. Petrović, O. Kosovac, N. Stanišić, D. Radojković, M. Mijatović
}

\section{Rezime}

Cilj rada je bio da se ispita uticaj rase oca (švedski landras i veliki jorkšir) i pola (ženski, muški kastrati) na kvalitet trupa i mesa svinja. Utvđena vrednost debljine slanine je bila najveća na grebenu $(33,21 \mathrm{~mm})$ a najtanja na krstima na sredini $\mathrm{m}$. gluteusa medius $(18,48 \mathrm{~mm})$. Rasa oca je uticala $(\mathrm{p}<0,01)$ na debljinu slanine na sredini leđa dok je pol uticao $(\mathrm{p}<0,05)$ na debljinu slanine na grbenu. Mesnatost potomaka švedskog landrasa utvrđena parcijalnom disekcijom EU iznosi $52,91 \%$ a po važećem Pravilniku 42,89 \% i veća je u odnosu na potomake (ŠLxVJ) čiji su očevi rase veliki jorkšir. Utvrđena razlika udela mesa između rasa očeva primenom ova dva metoda iznosi 10,02 i 8,83 \%. Veći udeo mesa (EU 53,20 \%) imali su ženski potomci za $2,27 \%$ u odnosu na muška $(\mathrm{p}<0,05)$. Takođe, rasa oca je uticala $(\mathrm{p}<0,05$ i $\mathrm{p}<0,01)$ na $\mathrm{pH}$, sposobnost vezivanja vode, mekoću i debljinu mišičnog vlakna dok je pol uticao $(\mathrm{p}<0,01)$ na boju $m$. longissimus dorsi. Rasa oca i pol nisu uticali na ispitivane hemijske osobine $m$. longissimus dorsi $(\mathrm{p}>0,05)$.

\section{References}

COMMISSION REGULATION (EC) No 3127/94 of 20 December 1994 amending Regulation (EC) No 2967/85 laying dowd detailed rules for the application of the Community scale for grading pig carcases (1994): Official Journal of the European Communities No L 330, 21/12/1994, 43-44.

GRAU R., UND HAMM R. (1953): Eine einfache Methode zur Bestimmung der Wasserbindung im Muskel. Naturwissenschaften, 40, 29-30

JUS ISO 1442 (1998)- Odredjivanje sadržaja vode

JUS ISO 936 (1999) - Odredjivanje sadržaja pepela

JUS ISO 1444 (1998) -Odredjivanje sadržaja slobodne masti

FISHER A.V., GREEN D.M., WHITTEMORE C.T., WOOD J.D., SCHOFIELD

C.P. (2003): Growth of carcass components and its relation with conformation in pigs of three types. Meat Science, 65, 1, 639-650. 
JUKNA V., JUKNA C. (2005): The comparable estimatimation of meat quality of pigs breeds and their combinations in Lithuania. Biotechnology in Animal Husbandry 21 (5-6), p. 175-179

HARVEY R.W. (1990): User's guide for LSMLMW and MIXMDL. Ver. PC-2, 1-91.

KNAPP P., WILLAM A., SÖLKNER J. (1997): Genetic parameters for lean meat content and meat quality traits in different pig breeds. Livestock Production Science, 52, 69-73.

KOSOVAC, O., PETROVIĆ, M., ŽIVKOVIĆ, B., FABJAN, M., RADOVIĆ, Č. (2002): Ocena nivoakvaliteta trupa sa gledišta udela tkiva u glavnim delovima svinjskih polutki.Biotechnology in Animal Husbandry, 18, 3-4, 21-26.

KOSOVAC O., N. STANIŠIĆ, B. ŽIVKOVIĆ, Č. RADOVIĆ, S. PEJČIĆ (2008): Kvalitet trupa i mesa svinja različitih genotipova. Biotecnology in Animal Husbandry, 24, 1-2, 77-86.

MIGDAL W., DOROTA WOJTYSIAK, P. PAŠCIAK, T. BAROWICZ, M. PIESZKA, KATARZYNA POLTOWICZ, B. ŽIVKOVIĆ, M. FABIJAN (2005): The Histochemical Profile of The Muscle Fibre In Fatteners - Genetic and NonGenetic Factors. Biotechnology In Animal Husbandry, 21, 5-6,169-174.

PETROVIĆ M., ŽIVKOVIĆ B., MIGDAL W., RADOJKOVIĆ D., RADOVIĆ Č., KOSOVAC O. (2004): The effect genetic and non-genetic factors on the quality of carcass and meat of pigs. International Conference "Pig and Poultry meat safety and quality-genetic and non-genetic factors", Krakow, 14-15october, 72.

PUŠIĆ M. (1996): Uticaj različitih genotipova na proizvodne osobine svinja u diskontinuiranom sistemu meleženja. Doktorska disertacija, Poljoprivredni fakultet, Zemun - Beograd, 1-130.

RADOVIĆ Č., PETROVIĆ M., JOSIPOVIĆ S., ŽIVKOVIĆ B., KOSOVAC O., FABJAN M. (2003): Uticaj različitih genotipova, očeva i sezone klanja na klanične osobine svinja. Biotechnology in Animal Husbandry, 19, 1-2, 11-16.

RADOVIĆ Č., M. PETROVIC, B. ŽIVKOVIĆ, O. KOSOVAC, N. PARUNOVIĆ (2008): The effect of different fixed factors on quality traits of pig carcass. Journal of Mountain Agriculture on the Balkans, 11, 4, 649-659.

SL SFRJ (1985): Pravilnik o kvalitetu zaklanih svinja i kategorizaciji svinjskog mesa. Službeni list SFRJ, 2, 20-30.

WALSTRA, P., and MERKUS, G.S.M.(1996). Procedure for assessment of the lean meat percentage as consequence of the new EU reference dissection method in pig carcass classification, Research Institute for Animal Science and Health Report,ID-DLO 96.014, 1-22, Research Branch, Zeist, The Netherlands. 